\title{
Investment Market Environment and Decision Making for Equity Portfolio Selection
}

\author{
Paluku Kazimoto \\ Faculty of Business Administration, Asia-Pacific International University, Muaklek, Thailand \\ Email: kazimoto@apiu.edu, pkazimoto@gmail.com
}

Received 25 March 2016; accepted 20 April 2016; published 26 April 2016

Copyright (C) 2016 by author and Scientific Research Publishing Inc.

This work is licensed under the Creative Commons Attribution International License (CC BY). http://creativecommons.org/licenses/by/4.0/

(c) (i) 0pen Access

\begin{abstract}
Decision making for portfolio selection is based on financial theory of modern portfolio and capital asset pricing model that have shaped way in which academics and practitioners analyze investment performance. Most of investors act rationally and consider all available information in the decision making process for efficiency reflecting all available information for security prices. This study aimed to examine the relationship between equity investment market environment and its portfolio selection decision-making in Arusha. This study employed descriptive and correlation research design. Purposive sampling method was applied to select 48 participants. A questionnaire was administered to collect data. Findings revealed that there was very high chance of the investors to make income out of their investments. Majority of respondents reported that market equity investment was very adequate to guarantee income from investment (mean $=3.63$ ), predict investment income for all the periods of investment (mean $=3.25)$, short term investment that was within 5 years (mean $=3.75$ ), access to equity investment information (mean $=4$ ), making proper decision on equity investment information (mean $=3.29$ ) and was with adequate managerial skills (mean $=3.13$ ). Results show that high return on investment (mean $=4.25$ ) was extremely adequate for equity investment portfolio selection, diversification (mean $=3.33$ ) and imitation and following (mean $=3.88$ ) were very adequate for equity investment portfolio selection, investment flexibility (mean $=3.04$ ) and investment status and prestige (mean $=3.13$ ) were adequate for equity investment portfolio selection. There was significant relationship between market equtiy investment environment and diversified investment portfolio selection decision. This study may serve as an eye opener to investors and mangers of companies to plan for business projects and equity investments in Arusha. There is a need to provide investors with information flow from the Bank of Tanzania and other financial institutions on investments.
\end{abstract}

\section{Keywords}

Learning on Investment, Portfolio Selection, Investors, Arusha 


\section{Introduction}

Equity investment generally refers to the business and holding of shares of stock on a stock market by individuals and companies in anticipation of income from dividends and capital to gain a rate value of the stock rises. Equity is viewed as private funds earned or reputation for generating returns above those of other markets. And that a prudent selection of portfolio offers a diversified exposure to attractive sources of risk premiums over long term [1].

Financing equity through capital markets plays a crucial role in the economy of countries. Equity capita ahs a continuing claim on corporate earnings and can be used to finance projects with uncertain and long-term returns [2]. Companies need equity to invest and grow and to generate the returns needed to service debts of other forms of capital. Also the association indicated that equity was the bedrock of economic growth.

It is observed that the capital of the bank based on its equity that includes share capital and reserves is subscribed and held only by the Government of the United of Tanzania. Bank of Tanzania's report [3] indicated that due to the nature of bank's business and statutory requirements the whole capital was mostly held in form of equity. The financial statement reports show a considerable increase in terms of equity. However, the report showed that there were still challenges faced by the Bank of Tanzania. There are principal risks that are mainly operational, human resources, legal, reputational and financial.

In Tanzania, companies raise finance through debt and equity. Investment is that since investment has been quite modest in the recent past, Tanzania is not a particularly promising external investment destination, or local private investment priority.

Decision making for portfolio selection is based on financial theory of modern portfolio and capital asset pricing model that have long shaped ways in which academics and practitioners analyze investment performance [4]. The investors act rationally and consider all available information in the decision making process for efficiency reflecting all available information in security prices [5]. Shiller [6] discovers that traditional finance paradigm assume that investors act rationally and consider all available information in the decision-making process. Investment market returns are believed to follow a random march pattern; hence considered unpredictable. It is found that the basic facts about the aggregate stock market, the cross-section average returns and individual trading behavior are not easily understood [7].

Portfolio selection for many investments limits to arbitrage, which allows investor irrationality to be substantial and have long-lived impact on prices. The need for taking into consideration investor's decision-making on portfolio selection has been a key point for investment diversity. This may lead to recognize that there exists knowledge of gap about the effect of market environment and portfolio selection among equity investment in Arusha. It may be recognized that people sometimes act in for their own best economic interests, and not considering that portfolio selection correctly described determine the way markets operate. Portfolio selection is a disposition effect among individual investors, which can be termed as a tendency to sell winners too soon and hold on to losers too long [8].

Investors make money when asset prices increase. Other investors take note of the profits being made, and they want to capture those profits as well. They buy the asset, and prices continue to rise. The higher prices rise and the longer it goes on, the more attention is brought to the positive price changes, and the more investors want to get involved. These investors are not buying because they think the asset is fairly valued, they are buying because the value is going up [9]. Investors tend to earn positive returns on sunny days and returns are mediocre on cloudy days. Hirshleifer and Shumway stated that this was evidence across a number of international markets. This suggests that investor mood affects the stock market, and that the effect is not due to the trading patterns of individual investors, thus leaving open the possibility that it may arise from the moods of market makers [10].

Financial market prices are driven at least in part by irrational agents [10] [11] and even if agents are riskneutral, overconfidence acts as a pre commitment to act aggressively, which causes the rational agent to scale back his trading activity [12]. When stock prices influence fundamentals by affecting corporate investment, irrational agents can earn greater expected profits than rational ones.

Investor trading has a significant systematic component, suggesting that the biases of individuals do not cancel in aggregate [13], and that [14] small traders buying the loser momentum stocks subsequently become sellers of those stocks. There are reference price effects that individuals are more likely to sell if the stock price attains a past month high [15]. There is a significant increase in volume if the stock achieves new maximum and mini- 
mum stock prices, again suggesting evidence of reference price effects.

Individual investors hold more under-diversified portfolios, and that they may exhibit stronger behavioral biases [16]. Investors have localized preferences for stock by documenting their preference for holding stocks in a regional telephone company in preference to other investments [17].

Preference for local stocks extends to mutual fund that tends to show a tendency for stocks in the region [18]. Two common mistakes investors make: excessive trading and the tendency to disproportionately hold on to losing investments while selling winners. They argue that these systematic biases have their origins in human psychology. The tendency for human beings to be overconfident causes the first bias in investors, and the human desire to avoid regret prompts to be the second bias [19] [20].

Security price over and under-reaction to information for investor judgment is biased by conservatism and the representativeness heuristic [21]. And price trend occur when a majority of market agents follow the same investing strategy (buying or selling), unsupported by new information [22].

Investors have ability to use leverage and portfolio should be used in nearly every market condition. Findings for his study show that for different periods of investment and especially over 15 years and if the volatility of the stock market continues, there will always be a need for diversified portfolios [23] [24].

The study aimed to analyze the factors of market investment environment and investor's portfolio selection decision. The analysis is based on the following hypothesis: there is no relationship between investment market environment and diversified equity portfolio selection decision-making.

\section{Methodology}

\subsection{Research Design}

This study employed the descriptive and correlation research design. Since the aim of his study was to determine the relationship between market of equity investment environment and diversified portfolio selection decision-making, the correlation design was considered as the appropriate method. This method helped to determine the effect of market of equity investment environment on the diversified portfolio selection decisions. The null hypothesis was analyzed from the statement that: there is no relationship between market environment and diversified portfolio selection decision-making on equity investment. The research was limited on learning of equity investment market environment and equity investment diversified portfolio selection decision making of investors in Arusha. The researcher did not include information related to bank services on equity investment.

\subsection{Participants, Sampling and Setting}

They are about 472 investor companies for general business in Arusha Region. The researcher dealt with investors that have used the banks for their investment. Purposive sampling method was applied to select 48 investors that work in business and equity investment. Majority (68\%) of respondents were male and $32 \%$ of them were female. More than half (56\%) of the respondents had been in business for the range of 1 to 5 years, $25 \%$ of them had been in business for the range of 6 to 15 years, and only 19\% of them have been in business investment for more than 15 years.

\subsection{Data Collection and Analysis}

The researcher used self-administered questionnaire as research tool to collect data from the respondents. The questionnaire was constituted into two main parts. The first part dealt with the investment market environment and the second part was concerned with the equity investment decision-making. For investment market environment we described the independents variables such as: market guarantee for investment income, sells and equity investment, long-term and short term investment, investment managerial skills, access to information on equity investment, ability to make decision on equity investment. The equity investment portfolio selection decision making involved: investment growth, return on investment, portfolio diversification, investment imitators and followers, investment flexibility and investment status and prestige. Although there was pilot study prior to this research, the questionnaire was verified and amended by professionals and fellow researchers and was proved reliable for data collection.

The SPSS statistical tool for data analysis helped the researcher to generate information from the collected data. Frequencies and mean were used to describe and analyze responses from respondents. Pearson moment 
correlation and multiple regressions were used to examine the relationship. To measure responses on the investment market environment and equity portfolio selection decision-making from the data gathered the mean values were ranged in the scale as follows: 4.20 - 5.00 Extremely adequate, 3.40 - 4.19 very adequate, 2.60 3.39 adequate, 1.80 - 2.59 poor and 1.00 - 1.79 very poor. Pearson moment correlation was utilized in determining the significance of relationship between the independent and dependent variables that stated: there is no relationship between variables. The decision rule was that if $p$ values are $>$ than 0.05 , the hypothesis is accepted and if $p$ values $<0.05$, the hypothesis is rejected.

\section{Results and Conclusion}

\subsection{Performance of Investment}

There was a need to find out if the investors were meeting their goals as expected. Findings show that majority (75\%) of the equity investors sampled in Arusha have met their performance goals that was ranged between 4\% and $6 \%, 25 \%$ of them achieved their goals put that was set at less than $2 \%$. Respondents (28.6\%) reported that growth of their assets was faster that could reduce the payback period of their investment capital; $24.5 \%$ had met their growing assets as expected; $24.5 \%$ had met income and growing their assets as set for investment goal; the remaining $20.4 \%$ had met income and protecting their assets as set for investment goal. These findings were supported [19], positively and authors stating that investors who choose to make investments are better performers, that overconfidence induces them to switch but then excessive trading after the switch dissipates their profits. Also in the same line [13] others indicated that individuals appear to particularly prefer stocks with lottery-like characteristics and [20] that individual investor trading has a significant systematic component, suggesting that the biases of individuals do not cancel in aggregate.

\subsection{Investment Market Environment}

Results revealed that $74 \%$ of respondents strongly agree that the investment market environment guarantee income from the investments and $26 \%$ disagree that on guarantee of income from investment market environment. The results show that there is a very adequate (mean $=3.63$ ) investment market environment in Arusha. Almost half (46\%) disagreed that investment market environment guarantee sells, 33\% of the respondents strongly disagreed (the findings show that there is absolutely a poor investment market environment with mean $=1.88$ for selling in Arusha) and only $21 \%$ of the respondents were neutral. The results are in line with the findings [10] authors agree that if agents are risk-neutral, overconfidence acts as a pre commitment to act aggressively, which causes the rational agent to scale back his trading activity. Also this may cause overconfident agents to earn greater expected profits than rational ones. When stock prices influence fundamentals by affecting corporate investment, irrational agents can earn greater expected profits than rational ones. On the other hand [9] author supports that the higher prices rise and the longer it goes on, the more attention is brought to the positive price changes and the more investors want to get involved. Added that investors are not buying because they think the asset is fairly valued, they are buying because the value is going up.

Findings show that $54 \%$ of respondents agreed that the investment market environment can predict to get sufficient income during all the periods of investments, $21 \%$ of respondents were neutral, $21 \%$ of them disagreed and only $4 \%$ of the respondents strongly disagreed that the investment market environment is unable to predict and generate sufficient income during all periods of investments. The assessment on the investment market environment shows a mean of 3.25 that means very adequate for predicting income during all the periods of investment. Majority (67\%) of the respondents strongly disagreed that investment market environment does facilitate long-term investment, and 33\% of respondents disagreed to have investment for more than 15 years. Which is confirmed the level of investment market environment that was very poor (mean $=1.33$ ). Findings show that $79 \%$ of respondents strongly agreed that investment market environment very adequate (mean $=3.75$ ) for short-term investment done within 5 years, $17 \%$ of respondents were neutral and only $4 \%$ of them disagree for investment within only 5 years. More that quarter (33\%) of the respondents agreed to have managerial skills for equity investment, $29 \%$ strongly disagreed, $21 \%$ s strongly agreed to have managerial skills for investments market environment, $13 \%$ of respondents were neutral and only $4 \%$ disagree to have managerial skills. This means that majority of the investors have managerial skills on equity investment and the market environment was adequate (mean $=3.13)$ for investment. 
There is very adequate (mean $=4$ ) market environment to access equity investment information. Half $(50 \%)$ of the respondents agreed that they had access to equity investment information, 33\% strongly agreed and only $17 \%$ disagree to have access information to equity investment. Majority (71\%) of the respondents indicated neutrality in their responses on having ability to make proper decision on equity investment and $29 \%$ of respondents reported that they did not have sufficient ability to make meaningful decisions on equity investments. Although majority was neutral on decision for equity investment but the mean (3.29) indicated that the market environment was very adequate for decision on equity investment. In contrast to above findings it was indicated [17] that investors have localized preferences for stock by documenting their preference for holding stocks in a regional company in preference to other investments. The selection is always the choice of investor.

\subsection{Factors for Investment Portfolio Selection and Decision-Making}

Findings indicate that half (50.0\%) of the respondents felt that the rate of activities of equity investment were very low, $41.7 \%$ of them indicated that the rate of activities of equity investment were moderate and only $4.3 \%$ of the respondent indicated very high. There was a mean of 2.17 implying that there is poor decision making on equity investment activities for portfolio selection. In relation to the findings [21] [22] it was argued that security prices of activities over and under-reaction to information when investor judgment is biased by conservatism and the representativeness heuristic illustrated the activity trend reversals often occur when a majority of market agents follow the same investing strategy (buying or selling), unsupported by new information.

The results show that $45.8 \%$ of the respondents reported that the returns from equity investments were very high, $33.3 \%$ of reported high and $20.8 \%$ of them reported moderate. This implies that decision-making was based on returns with the mean of 4.25 indicating that there is extremely adequate decision-making based on investment returns. Majority (66.7\%) of the respondents indicated that decision-making on diversification of equity investment portfolio was moderate and $33.3 \%$ of them reported high. This was supported by mean of 3.33 that shows adequate decision making for investment based on diversification. The results show that $45.8 \%$ of respondents reported that decision-making on imitating and following other investors' decisions for equity investment was high, $33.3 \%$ of the respondents reported moderate and $20.8 \%$ of them reported very high. This implies that decision-making was very adequate (mean of 3.88) based on imitation and following other investments. The level of flexibility in decision making for equity investments was reported moderate by majority (62.5\%) of respondents, $20.8 \%$ of them indicated high and $16.7 \%$ of respondents reported low. The mean (3.04) calculated show that there was adequate decision making based on investment flexibility. Majority (62.5\%) of the respondents reported moderate on the decision making of investment based on status and prestige, $29.2 \%$ of the respondents reported high and only $8.3 \%$ of them rated low. This means that the decision-making based on investment status and prestige was adequate (mean $=3.13$ ). Supported by the investment theory [5] and Capital Asset Pricing Model [4] have long shaped the way in which academics and practitioners analyze investment performance. The theory is based on the notion that investors act rationally and consider all available information in the decision-making process, and hence investment markets are efficient, reflecting all available information in security prices. The results also align with Barber and Odean [8] that highlighted two common mistakes investors make: excessive trading and the tendency to disproportionately hold on to losing investments while selling winners. They argue that these systematic predispositions have their origins in human psychology. The tendency for human beings to be overconfident causes the first bias in investors, and the human desire to avoid regret prompts the second.

\subsection{Relationship between Investment Market Environment and Equity Portfolio Selection Decision-Making}

The relationship was analyzed from the categories of investment market environment such as market guarantee income from investments, long term and short-term investment periods, managerial skills for investment and ability to carry out equity investment portfolio. For the equity investment portfolio selection decision-making, diversified portfolio factor was considered.

The findings indicated that there is very significant positive relationship of market guarantee income from investments and diversified portfolio $(r=0.650)$, which implies that the more there is a guarantee to have income, higher investors make adequate decision to diversify their equity investment portfolio. There is very significant relationship between to predict sufficient income during all periods of investment and diversified portfolio deci- 
sion making $(r=0.574)$, meaning that the more there is diversified portfolio, the higher prediction of returns at all periods increase. The results show that there is strong relationship but negative between long-term investment and diversified portfolio $(r=-0.500)$, which means that the more diversified portfolio increase the less decision making for portfolio selection is made based on long-term investment. There is a significant positive relationship between short-term investment and diversified portfolio $(r=0.340)$. This implies that the increase of equity investment in short-term influence highly the decision-making for diversified equity portfolio selection. It is evidenced that there is very significant positive relationship between managerial skills and decision making on equity investment and diversified portfolio selection $(r=0.442)$.

On the other hand the correlation coefficient of determination represented by $R=68.8 \%$ and $R$ square $=47.4 \%$ with a p value of 0.001 explains the relationship between the variables and how the investment market environment influence the decision-making on diversification of equity investment portfolio.

In determining the significant of relationship between investment market environment and diversified of equity portfolio selection decision-making, findings in Table 1 of critical values from Pearson product moment correlation was utilized. The critical value for the sample was that if $p>0.05$ the hypothesis is accepted, which stated: <there is no relationship between investment market environment and diversified equity investment portfolio selection decision-making>. Thus for the sample in Table 1, $p$ values were less than 0.05 ; therefore the alternative hypothesis is rejected. The rejection of alternative hypothesis led to the acceptance of null hypothesis that will state: <there is a significant relationship between investment market investment environment and diversified equity portfolio selection decision-making>. Results are supported by authors [16] [23] that portfolio should be used in nearly every market condition and that investors hold more diversified portfolios that exhibit stronger behavioral on investment.

\section{Conclusions}

Findings indicate that majority of respondents reported that investment market environment was very adequate to guarantee income from investment (mean $=3.63$ ), predict investment income during all the periods of businesses (mean $=3.25$ ), for short term investment within 5 years (mean $=3.75$ ), access to equity investment information (mean $=4$ ), making proper decision on equity investment information (mean $=3.29$ ) and adequate managerial skills (mean $=3.13$ ). Results show that high return on investment (mean $=4.25)$ was extremely adequate for equity portfolio selection decision, diversification (mean $=3.33$ ) and imitation and following (mean = 3.88) were very adequate for equity portfolio selection decision making, investment flexibility (mean $=3.04$ ) and investment status and prestige (mean $=3.13$ ) were adequate for equity diversified portfolio selection decision making.

The very significant relationship between investment market environment and diversified equity portfolio decision implies that the greater the awareness on market environment, the more enhanced decision on diversificaiton for investment portfolio selection. This study may serve as an eye opener to investors and managers of companies to plan for business projects and equity investments in Arusha.

Findings reveal that there is a very high chance of investors to make more income out of their investments than they are presently making. There is a need to provide investors with information flow from the Banks in Tanzania and other financial institutions on investments portfolio selection.

Table 1. Relationship between investment market environment and equity portfolio selection decision-making.

\begin{tabular}{ccc}
\hline Market Equity Investment Environment & Diversified Equity Portfolio & Decision \\
\hline Market Guarantee income from investment & $.650^{* *}$ & $.574^{* *}$ \\
Predict sufficient income all periods of investment & $-.500^{* *}$ & Reject \\
Long term investment & $.340^{*}$ & $.442^{* *}$ \\
Short term investment & thesis \\
Investment managerial skills for equity investment &
\end{tabular}

\footnotetext{
${ }^{*}$ Correlation is significant at the 0.05 level (2-tailed). ${ }^{* *}$ Correlation is significant at the 0.01 level (2-tailed).
} 
From the study the following recommendations are elaborated:

- A study is needed in the area of companies and capital market to find out how shares are issued in the market to allow investors to trade.

- More research are suggested in line with of this study, especially for the analysis of the equity market in relation to economic growth, and also find out other factors influencing investments and portfolio selection for the economic growth in the county.

\section{References}

[1] Picket Alternative Advisors SA (2104) An Introduction to Private Equity. https://www.pictet.com/content/dam/pictet_documents/pdf_documents/pai_documentation/introduction_private-equity en.pdf

[2] Association of British Insurers (2013) Encouraging Equity Investment: Facilitation of efficient Equity Capital Raising in the UK Market. https://www.ivis.co.uk/media/5926/ABI-Encouraging-Equity-Investment-report-July-2013.pdf

[3] Bank of Tanzania (2014) Directors report and Financial Statements for the Year Ended 20 June 2014. Tanzania.

[4] Sharpe, W. (2003) Capital Asset Prices: A Theory of Market Equilibrium under Conditions of Risk. Journal of Finance, 91, 425-442.

[5] Markowitz, H. (2005) Portfolio Selection. Journal of Finance, 7, 77-91.

[6] Shiller, R.J. and Karl, E.C. (2004) Is There a Bubble in the Housing Market. Cowles Foundation for Research in Economics Yale University, New Haven. http://cowles.econ.yale.edu

[7] Lusht, K.M. (2008) The Real Estate Pricing Puzzle. Real Estate Economics, 16, 95-104. http://dx.doi.org/10.1111/1540-6229.00448

[8] Barber, B.M. and Odean, T. (2006) All That Glitters: The Effect of Attention and News on the Buying Behavior of Individual and Institutional Investors. The Review of Financial Studies. http://faculty.haas.berkeley.edu/odean/papers/attention/all\%20that\%20glitters.pdf

[9] Pompian, M.M. (2006) Behavioral Finance and Wealth Management: How to Build Optimal Portfolio that account for Invest Biases. John Willey \& Sons Inc., Canada.

[10] Hirshleifer, D.A. and Shumway, T. (2001) Good Day Sunshine: Stock Returns and the Weather (March 28, 2001). Dice Center Working Paper No. 2001-3. http://ssrn.com/abstract=265674

[11] Athely, S., Bagwel, K. and Sanchirico, C. (2004) Collusion and Price Rigidity. Review of Economic Studies, 71, 317349. http://dx.doi.org/10.1111/0034-6527.00286

[12] Dong, M., Hirshleifer, D., Richardson, S. and Teoh, H.S. (2006) Does Investor Misvaluation Drive the Takeover Market? The Journal of Finance, 61, 725-762. http://dx.doi.org/10.1111/j.1540-6261.2006.00853.x

[13] Kumar, A. and Lee, C.M.C. (2006) Retail Investor Sentiment and Return Comovements. The Journal of Finance, 61, 2451-2486. http://dx.doi.org/10.1111/j.1540-6261.2006.01063.x

[14] Hvidkjaer, S. (2006) A Trade-Based Analysis of Momentum. Review of Financial Studies, 19, 457-491. http://dx.doi.org/10.1093/rfs/hhj016

[15] Kaustia, M. (2004) Market-Wide Impact of the Disposition Effect: Evidence from IPO Trading Volume. Journal of Financial Markets, 7, 207-235. http://finance.aalto.fi/en/people/kaustia/

[16] Goetzmann, W.N. and Kumar, A. (2003) Diversification Decisions of Individual Investors and Assets Prices. https://ideas.repec.org/p/ysm/somwrk/ysm441.html

[17] Huberman, G. (2001) Familiarity Breeds Investments. Oxford Journals Social Sciences Review of Financial Studies, 14, 659-668. http://dx.doi.org/10.1093/rfs/14.3.659

[18] Coval, J.D. and Shumway, T. (2000) Expected Option Returns. http://www-personal.umich.edu/ shumway/papers.dir/optret.html

[19] Barber, B.M. and Odean, T. (2002) Online Investors: Do the Slow Die First? Review of Financial Studies, 15, 455-488. http://dx.doi.org/10.1093/rfs/15.2.455

[20] Barber, B., Odean, T. and Zhu, N. (2003) Systematic Noise. Working Paper, University of California, Davis.

[21] Barberis, N., Shleifer, A. and Vishny, R.A. (2006) Model of Investor Sentiment. Journal of Financial Economics, 49, 307-343. http://dx.doi.org/10.1016/S0304-405X(98)00027-0

[22] Chan, L.K.C., Lakonishok, J. and Sougiannis, T. (2001) The Stock Market Valuation of Research and Development of Expenditures. The Journal of Finance, 56, 2431-2456. http://dx.doi.org/10.1111/0022-1082.00411 
[23] Koerten, K.T. (2013) Comparing Portfolio Diversification Strategies in Different Market Environments. University of Tennessee Honors Thesis Projects. http://trace.tennessee.edu/utk_chanhonoproj/1643

[24] Shleifer, A. and Vishny, R. (1997) The Limits of Arbitrage. Journal of Finance, 52, 35-55. 